\title{
Effects of Inoculants (Chlorobium limicola and Rhodopseudo- monas palustris) on Nutrient Uptake and Growth in Cucumber
}

\author{
Shuang Shao ${ }^{1, *}$, Hongyao Zhao ${ }^{1}$, Xiaolei Guo ${ }^{2}$, Lijie Guan ${ }^{1}$ and Haiyan $\mathrm{Li}^{1}$ \\ ${ }^{1}$ College of Pharmaceutical and Biological Engineering, Shenyang University of Chemical Technology, \\ 110142, Liaoning, China \\ ${ }^{2}$ Liaoning Provincial Seed Administration, 110034, Liaoning, China
}

\begin{abstract}
Rhizobacteria is a prosperous for promoting plant growth for the superiority of reducing environmental damages. Two Strains of Chlorobium limicola and Rhodopseudomonas palustris were supplied in the experiment as potential inoculants for cucumber. Significant enhancement of the availability of macronutrient elements N, P and K were observed in soil, and further improvement on the uptake of them was also obtained in cucumber plants. Accumulation of essential micronutrients of $\mathrm{Fe}$ and $\mathrm{Zn}$ were detected both in roots and in shoots. The two stains increased chlorophyll and carotinoid synthesis, plant height, stem diameter, wet weight and dry weight. Various dose has significantly effect on plant growth stimulation, C. Limicola with $10^{7}$ cells $\mathrm{mL}^{-1}$ and $R$. Palustris with $10^{8}$ cells $\mathrm{mL}^{-1}$ seem to be better on the whole.
\end{abstract}

Keywords: Biofertilizer, cucumber, growth, nutrien.

\section{INTRODUCTION}

Utilization of fertilizers is really necessary for plant growth, but excessive and repeated use of chemical fertilizers may spoil the soil, water and even atmosphere [1]. Rhizobacteria containing biofertilizers are perfect tools to improve plant nutrient and production and reduce environmental damages [2]. Nitrogen, phosphorus and potassium are major limiting factors to plant growth. Plant growth promoting rhizobacteria (PGPR) including $\mathrm{N}$ - fixe, phosphate and potassium solubilizing bacteria (PSB and $\mathrm{KSB}$ ) stimulate the growth of plants by helping to provide nutrient to the host plant, or indirectly by positively influencing root growth and morphology or by aiding other beneficial symbiotic relationships, or helping to control pathogenic organism [3, 4]. Chlorobium limicola and Rhodopseudomonas palustris are the diverse group of photosynthetic prokaryotes growing frequently in soils, which are known to fix atmospheric nitrogen[5] and induce resistance, seem to achieve their promised contribution to plant growth. Micronutrient elements are essential to both plant growth and human health. About one third people in the world suffer from the inadequate intakes of $\mathrm{Fe}, \mathrm{Zn}$ and vitamin $\mathrm{A}$ [6], especially in developing countries [7]. Cucumber (Cucumis sativus L.) cultivation has an important role in agricultural production, especially under protection. Nutrients are required for maximum growth rate of cucumber. And the optimal weight proportions among the nutrients

*Address correspondence to this author at the College of Pharmaceutical and Biological Engineering, Shenyang University of Chemical Technology, 110142, Liaoning, China; Tel: 86-024-13840034285; Fax: 86-024-89385582;

E-mail: shaoshuang403@163.com maybe is that, in relation to $\mathrm{N}=100$, close to $75 \mathrm{~K}, 13$ $\mathrm{P}, 9 \mathrm{Ca}$, and $9 \mathrm{Mg}$. In present study, we checked the role of the two strains in macronutrient and micronutrient elements uptake and growth promotion of cucumber.

\section{MATERIALS AND MATHODS}

Chlorobium limicola and Rhodopseudomonas palustris are two newly isolated strains of photosynthetic bacteria. Seeds of cucumber (Cucumis sativus L. cv. Jinchun4) were surface sterilized with $\mathrm{HgCl}_{2}(0.1 \%)$ for $10 \mathrm{~min}$, rinsed with deionized water and placed on filter paper moistured by deionized water, and germinated at $28^{\circ} \mathrm{C}$ in constant temperature incubator in dark. After germination the seedlings were transferred to plastic pot $\left(\Phi_{\text {bottom }} 10 \mathrm{~cm} \times 16 \mathrm{~cm} \times\right.$ $\left.\Phi_{\text {top }} 15 \mathrm{~cm}\right)$ containing $1.2 \mathrm{~kg}$ autoclaved soil. The cells in cul-tured bacterial broth of both two strains were adjusted to $10^{7}, 10^{8}$ and $10^{9}$ cells $\mathrm{mL}^{-1}$, and $150 \mathrm{~mL}$ of bacterial broth was applied to each pot every two days, and the application of deionized water and chemical fertilizer were using as controls. The experiment of examining cucumber growth was set in a Completely Randomized Block Design with eight treatments each content four replicates and the replicate represented by ten plants under controlled conditions at $26 \pm 2^{\circ} \mathrm{C}$ and a $16 \mathrm{hr}$ photoperiod created by using illumination incubator. The morphological characters such as height of the plants, stem diameter, wet weight and dry weight were esti-mated at 40 days after treatment are calculated. We used the Minolta SPAD-502 chlorophyll meter, \pm 1.0 SPAD (arbitrary units), to measure the relative chlorophyll contents and chromatography for carotinoid contents of the third fully developed leaves. 
Shoot and root tissues were separated after harvesting and were air-dried at $70^{\circ} \mathrm{C}$ for 5 days, and soil samples were collected after the experiment and air-dried for chemical analysis. Plants were digested in $\mathrm{H}_{2} \mathrm{SO}_{4}-\mathrm{H}_{2} \mathrm{O}_{2}$ for the determination of total nitrogen. Available $\mathrm{N}$ in soils was determined by alkalineproliferation law. $\mathrm{P}$ was determined by the Berthelot reaction and molybdenum blue method [8], soil samples were extracted with $0.5 \mathrm{M} \mathrm{NaHCO}_{3}(\mathrm{pH} 8.5)$. Plants and soils were digested using $1 \mathrm{M} \mathrm{NH}_{4} \mathrm{OAC}(\mathrm{pH}$ 7) for the determination of $\mathrm{K}$ using an atomic absorption spectrometer. Atomic absorption spectrometer was also used for the determination of Fe and $\mathrm{Zn}$ [9].

The data was analyzed statistically for standard deviation by using sigma plot software. The mean values were compared, using Duncan's multiple range test at $\mathrm{P}<0.05$.

\section{RESULTS}

The treatment inoculation with C. Limicola and $R$. Palustris significantly increased $\mathrm{N}, \mathrm{P}$ and $\mathrm{K}$ uptake in cucumber plants. The two strains had stronger effect on $\mathrm{N}$ uptake then $\mathrm{P}$ and $\mathrm{K}$ uptake. The amounts of available $\mathrm{N}, \mathrm{P}$ and $\mathrm{K}$ nutrients in soils were significantly increased as compared to control, which might be attribute to the capability to fix atmospheric nitrogen, solubilize phosphate and potassium by C. Limicola and R. Palustris. R. Palustris with $10^{8}$ cells $\mathrm{mL}^{-1}$ and $C$. limicola with $10^{7}$ cells $\mathrm{mL}^{-1}$ have even stronger and more stable effect then with other concentrations (Table 1).

Accumulation of $\mathrm{Fe}$ in both plant parts of roots and shoots increased significantly in various treatments of C. Limicola and R. Palustris as compared to the control of deionized water, and even higher then the control of chemical fertilizer in roots, and reaching to the maximum level in $R$. Palustris with $10^{8}$ cells $\mathrm{mL}^{-1}$. Level of $\mathrm{Zn}$ showed similar trend with that of $\mathrm{Fe}$ except reaching to the maximum level in C. Limicola with $10^{7}$ cells $\mathrm{mL}^{-1}$ in roots and $R$. Palustris with $10^{7}$ cells $\mathrm{mL}^{-1}$ in shoots. It is obviously that the two stains could promote the enrich of $\mathrm{Fe}$ and $\mathrm{Zn}$ in cucumber, and the effect seems to be stronger in roots than in shoots (Table 2).

Table 1: Effects of C. Limicola and R. Palustris on Macronutrient Uptake of Cucumber and on the Available N, P, K Concentrations in the Soils $(n=4 ; \pm$ s.e.)

\begin{tabular}{|c|c|c|c|c|c|c|}
\hline \multirow{2}{*}{ Treatment (cells $\mathbf{~ m L}^{-1}$ ) } & \multicolumn{3}{|c|}{ cucumber(mg.g dw ${ }^{-1}$ ) } & \multicolumn{3}{c|}{ soils $\left(\mathbf{m g ~ k g}^{-1}\right)$} \\
\cline { 2 - 7 } & $\mathbf{N}$ & $\mathbf{P}$ & $\mathbf{K}$ & $\mathbf{N}$ & $\mathbf{P}$ & $\mathbf{K}$ \\
\hline \hline deionized water & $19.1 \pm 0.82 \mathrm{c}$ & $1.83 \pm 0.10 \mathrm{~b}$ & $27.5 \pm 2.41 \mathrm{~b}$ & $70.12 \pm 4.32 \mathrm{c}$ & $8.92 \pm 0.50 \mathrm{~d}$ & $80.22 \pm 7.8 \mathrm{c}$ \\
\hline R. palustris $\left(10^{7}\right)$ & $22.3 \pm 0.78 \mathrm{ab}$ & $2.09 \pm 0.08 \mathrm{a}$ & $31.6 \pm 2.01 \mathrm{a}$ & $92.75 \pm 5.19 \mathrm{a}$ & $10.89 \pm 0.67 \mathrm{ab}$ & $98.07 \pm 8.5 \mathrm{~b}$ \\
\hline R. palustris $\left(10^{8}\right)$ & $22.4 \pm 0.98 \mathrm{a}$ & $2.06 \pm 0.11 \mathrm{a}$ & $31.5 \pm 1.93 \mathrm{a}$ & $98.85 \pm 2.07 \mathrm{a}$ & $10.65 \pm 0.81 \mathrm{ab}$ & $110.16 \pm 10.5 \mathrm{a}$ \\
\hline R. palustris $\left(10^{9}\right)$ & $20.0 \pm 1.11 \mathrm{bc}$ & $2.04 \pm 0.08 \mathrm{a}$ & $30.5 \pm 2.21 \mathrm{a}$ & $88.80 \pm 3.55 \mathrm{ab}$ & $10.31 \pm 0.15 \mathrm{bc}$ & $98.97 \pm 8.7 \mathrm{~b}$ \\
\hline C. limicola $\left(10^{7}\right)$ & $21.8 \pm 0.83 \mathrm{ab}$ & $2.10 \pm 0.10 \mathrm{a}$ & $31.0 \pm 1.58 \mathrm{a}$ & $82.63 \pm 4.25 \mathrm{ab}$ & $11.33 \pm 0.38 \mathrm{a}$ & $112.34 \pm 5.6 \mathrm{a}$ \\
\hline C. limicola $\left(10^{8}\right)$ & $20.4 \pm 1.02 \mathrm{bc}$ & $2.12 \pm 0.14 \mathrm{a}$ & $30.2 \pm 1.33 \mathrm{a}$ & $90.76 \pm 1.77 \mathrm{ab}$ & $11.50 \pm 1.16 \mathrm{a}$ & $94.61 \pm 7.2 \mathrm{~b}$ \\
\hline C. limicola $\left(10^{9}\right)$ & $21.6 \pm 1.30 \mathrm{ab}$ & $2.08 \pm 0.09 \mathrm{a}$ & $30.6 \pm 2.71 \mathrm{a}$ & $81.74 \pm 1.84 \mathrm{~b}$ & $9.62 \pm 1.27 \mathrm{~cd}$ & $95.32 \pm 5.8 \mathrm{~b}$ \\
\hline
\end{tabular}

Table 2: Effect of C. Limicola and R. Palustris on the Contents of Fe and Zn in Cucumber (n=4; $\pm \mathrm{s} . e).\left(\mathrm{mg} . \mathrm{kg} \mathrm{dw}^{-1}\right)$

\begin{tabular}{|c|c|c|c|c|}
\hline \multirow{2}{*}{ Treatment (cells $\mathrm{mL}^{-1}$ ) } & \multicolumn{2}{|c|}{ roots } & \multicolumn{2}{c|}{ shoots } \\
\cline { 2 - 5 } & Fe & Zn & $532.7 \pm 19.5 \mathrm{c}$ & $146.6 \pm 4.68 \mathrm{c}$ \\
\hline \hline deionized water & $415.6 \pm 18.3 \mathrm{e}$ & $123.1 \pm 3.21 \mathrm{~d}$ & $608.9 \pm 20.2 \mathrm{abc}$ & $176.2 \pm 3.11 \mathrm{ab}$ \\
\hline chemical fertilizer & $475.5 \pm 17.6 \mathrm{~d}$ & $144.6 \pm 4.44 \mathrm{c}$ & $612.8 \pm 21.8 \mathrm{ab}$ & $182.7 \pm 4.65 \mathrm{a}$ \\
\hline R. palustris $\left(10^{7}\right)$ & $601.4 \pm 16.4 \mathrm{ab}$ & $156.8 \pm 2.61 \mathrm{~b}$ & $654.4 \pm 16.4 \mathrm{a}$ & $175.5 \pm 4.12 \mathrm{ab}$ \\
\hline R. palustris $\left(10^{8}\right)$ & $655.4 \pm 20.5 \mathrm{a}$ & $166.2 \pm 0.98 \mathrm{ab}$ & $572.7 \pm 17.2 \mathrm{bc}$ & $174.2 \pm 2.08 \mathrm{ab}$ \\
\hline R. palustris $\left(10^{9}\right)$ & $602.8 \pm 17.5 \mathrm{ab}$ & $167.5 \pm 5.21 \mathrm{ab}$ & $594.6 \pm 18.5 \mathrm{abc}$ & $178.4 \pm 1.22 \mathrm{ab}$ \\
\hline C. limicola $\left(10^{7}\right)$ & $588.2 \pm 21.4 \mathrm{bc}$ & $174.9 \pm 3.89 \mathrm{a}$ & $566.2 \pm 18.9 \mathrm{bc}$ & $175.9 \pm 5.97 \mathrm{ab}$ \\
\hline C. limicola $\left(10^{8}\right)$ & $532.3 \pm 18.2 \mathrm{c}$ & $162.8 \pm 4.56 \mathrm{ab}$ & $548.3 \pm 17.7 \mathrm{c}$ & $165.8 \pm 3.26 \mathrm{~b}$ \\
\hline C. limicola $\left(10^{9}\right)$ & $560.1 \pm 18.6 \mathrm{bc}$ & $170.8 \pm 2.17 \mathrm{a}$ & & \\
\hline
\end{tabular}


Table 3: Effects of C. Limicola and R. palustris on the Plant Height, Stem Diameter, Wet Weight, Dry Weight, Relative Chlorophyll Contents and Carotinoid Contents of Cucumber $(n=4 ; \pm s . e$.

\begin{tabular}{|c|c|c|c|c|c|c|}
\hline $\begin{array}{l}\text { Treatment } \\
\text { (cells } \mathrm{mL}^{-1} \text { ) }\end{array}$ & $\begin{array}{c}\text { Height } \\
\left(\mathrm{cm} \text { plant }^{-1}\right)\end{array}$ & $\begin{array}{l}\text { stem diameter } \\
\left(\mathrm{cm} \mathrm{plant}^{-1}\right)\end{array}$ & $\begin{array}{l}\text { wet weight } \\
\text { (g plant }^{-1} \text { ) }\end{array}$ & $\begin{array}{l}\text { dry weight } \\
\left.\text { (g plant }^{-1}\right)\end{array}$ & $\begin{array}{l}\text { Chlorophyll } \\
\left(\mathrm{mg} \mathrm{g}^{-1}\right)\end{array}$ & $\begin{array}{l}\text { Carotinoid } \\
\left(\mathrm{mg} \mathrm{g}^{-1}\right)\end{array}$ \\
\hline deionized water & $13.8 \pm 0.86 \mathrm{e}$ & $1.37 \pm 0.05 d$ & $7.37 \pm 0.84 \mathrm{e}$ & $0.72 \pm 0.11 \mathrm{c}$ & $10.0 \pm 0.82 d$ & $3.25 \pm 0.48 b$ \\
\hline chemical fertilizer & $14.1 \pm 1.29 \mathrm{e}$ & $1.40 \pm 0.07 \mathrm{~cd}$ & $7.51 \pm 0.62 \mathrm{de}$ & $0.74 \pm 0.07 \mathrm{c}$ & $10.6 \pm 0.98 c$ & $2.99 \pm 0.71 \mathrm{c}$ \\
\hline R. palustris $\left(10^{7}\right)$ & $25.6 \pm 0.76 a$ & $1.43 \pm 0.06 \mathrm{bcd}$ & $9.98 \pm 0.91 a$ & $0.88 \pm 0.02 a$ & $11.1 \pm 0.89 b$ & $3.55 \pm 0.27 a$ \\
\hline R. palustris $\left(10^{8}\right)$ & $25.0 \pm 0.84 a$ & $1.43 \pm 0.16 \mathrm{bcd}$ & $9.98 \pm 0.01 a$ & $0.88 \pm 0.22 a$ & $11.8 \pm 0.52 a$ & $3.64 \pm 0.67 a$ \\
\hline R. palustris $\left(10^{9}\right)$ & $15.0 \pm 1.28 d$ & $1.47 \pm 0.14 \mathrm{bc}$ & $7.96 \pm 0.92 \mathrm{~cd}$ & $0.61 \pm 0.01 d$ & $6.50 \pm 0.99 \mathrm{e}$ & $1.80 \pm 0.20 d$ \\
\hline C. limicola $\left(10^{7}\right)$ & $23.1 \pm 0.42 b$ & $1.50 \pm 0.10 \mathrm{ab}$ & $8.10 \pm 0.62 c$ & $0.62 \pm 0.02 d$ & $11.6 \pm 1.38 \mathrm{ab}$ & $1.89 \pm 0.28 d$ \\
\hline C. limicola $\left(10^{8}\right)$ & $18.2 \pm 1.36 \mathrm{c}$ & $1.57 \pm 0.03 a$ & $9.05 \pm 0.61 b$ & $0.71 \pm 0.08 \mathrm{c}$ & $11.2 \pm 1.35 b$ & $3.57 \pm 0.71 \mathrm{a}$ \\
\hline C. limicola $\left(10^{9}\right)$ & $21.5 \pm 0.46 b$ & $1.57 \pm 0.22 a$ & $10.0 \pm 0.673 a$ & $0.80 \pm 0.06 \mathrm{~b}$ & $10.1 \pm 0.74 d$ & $3.26 \pm 0.09 b$ \\
\hline
\end{tabular}

Both strains showed a promoting effect on plant growth, morphological and biochemical parameters repre-senting at Table 3 showed a best response to the R. Palustris inoculants with $10^{8}$ cells $\mathrm{mL}^{-1}$, and treatment with $10^{7}$ cells $\mathrm{mL}^{-1}$ is following. Morphological parameters showed a good response to $C$. limicola with $10^{9}$ cells $\mathrm{mL}^{-1}$, however, several parameters responsing to $R$. Palustris with $10^{8}$ cells $\mathrm{mL}^{-1}$ were lower then control (Table 3).

\section{DISCUSSION}

The experiment demonstrated that C. Limicola and $R$. Palustris stimulated the availability of the macronutrient element $\mathrm{N}, \mathrm{P}$ and $\mathrm{K}$ in soils, and make further improvement on the uptake of them in cucumber plants. The two stains could also promote the accumulation of essential micronutrients of $\mathrm{Fe}$ and $\mathrm{Zn}$. This probably due to the effect of bacteria on creasing the availability of $\mathrm{Fe}$ and $\mathrm{Zn}$. $\mathrm{Fe}$ is the maximum micronutrient for plant growth. Fe and $\mathrm{Zn}$ can accelerate chlorophyll synthesis. So we can see the application of the two stains enhanced growth, while the probably physiological basis might be that an increased chlorophyll and carotinoid synthesis makes a stronger photosynthesis, photosynthesis may additionally provides energy for nitrogen fixation, allowing for more efficient plant growth [10], therefore, wet weight and dry weight enhanced, and a more intensive uptake of nutrients might also cause a promoting growth of cucumber [11]. The increasing $\mathrm{N}$ uptake in our experiment might be related to the fact that photosynthetic bacteria which $C$. Limicola and $R$. Palustris falls into is a genus which fixes atmospheric nitrogen [12]. Whether the increasing uptake of $P$ and $\mathrm{K}$ should due to the role of strains by aiding other beneficial symbiotic relationships or their own role needs further reaserch. The perfect behaviour of the two strains appears therefore a priority to really envisage a future for the use of them as an inoculant for cucumber.

\section{ACKNOWLEDGEMENTS}

This research was financially supported by Shenyang University of Chemical Technology and a grand from Shenyang Science and technology bureau (no. F12-108-3-00). The helpful comments of the editor and anonymous reviewers are gratefully acknowledged.

\section{REFERENCES}

[1] Mytton L. Nitrogen Fixation In Institute of Grassland and Environmental Research Rep. Institute of Grassland and Environ. Res. Aberystwyth, UK 1993; p. 46-5.

[2] Vessey JK. Plant growth promoting rhizobacteria as biofertilizers. Plant Soil 2003; 255: 571-16. http://dx.doi.org/10.1023/A:1026037216893

[3] Whipps JM. Microbial interactions and biocontrol in the rhizosphere. J Exp Bot 2001; 52: 487-25. http://dx.doi.org/10.1093/jexbot/52.suppl 1.487

[4] Zehnder GW, Murphy JF, Sikora EJ, Kloepper JW. Application to rhizobacteria for induced resistance. Eur $\mathrm{J}$ Plant Pathol 2001; 107: 39-12. http://dx.doi.org/10.1023/A:1008732400383

[5] Paul WL, Gary PR. Nitrogen fixation by photosynthetic bacteria. Photosynth Res 2002; 73: 115-4. http://dx.doi.org/10.1023/A:1020497619288

[6] Food and Agriculture Organization of the United Nations (FAO). Preventing micronutrient malnutrition. A guide to foodbased approaches. International Life Science Institute: Washington DC 1997.

[7] Miflin B. Crop biotechnology. Where now? Plant Physiol 2000; 123: 17-12. http://dx.doi.org/10.1104/pp.123.1.17

[8] Page AL, Mille RH, Keeney DR. Methods of Soil Analysis: Part 2. Chemical and Microbiological Properties $2^{\text {nd }}$ ed. Amer Society of Agronomy 1982; 9: 1159.

[9] Han YS. The Experimental Technology of Food Chemistry. Agricultural University. Beijing Chin (in Chinese) 1996. 
[10] Giraud E, Fleischman D. Nitrogen-fixing symbiosis between photosynthetic bacteria and legumes. Photosynth Res 2004; 82: $115-6$. http://dx.doi.org/10.1007/s11120-004-1768-1

[11] Lévai L. Bacteria containing fertilizer: A tool for sustainable agriculture. XV. International Plant Nutrition Colloquium, Peking 2005.
[12]

Han HS, Supanjani, Lee KD. Effect of co-inoculation with phosphate and potassium solubilizing bacteria on mineral uptake and growth of pepper and cucumber. Plant Soil Environ 2006; 52: 130-7. 